\title{
Study Profile of the Pomegranate Growers
}

\author{
S. D. Bhoyar*, R. D. Ahire and P. S. Kapse \\ ${ }^{1}$ Department of Extension Education, College of Agriculture, Parbhani \\ ${ }^{2}$ College of Agriculture, Osmanabad \\ Vasantrao Naik Marathwada Krishi Vidyapeeth, Parbhani (M.S.), India \\ *Corresponding author
}

K e y w o r d s
Profile,
Pomegranate
growers,
Information
management
behaviour
Article Info
Accepted:
14 November 2020
Available Online:
10 December 2020

\section{A B S T R A C T}

The present study was conducted with the specific objective of "Profile of the pomegranate growers". For the study, Aurangabad district was purposively selected for the present study as it is one of the maximum pomegranate growing district of Marathwada region. There are nine talukas in Aurangabad district out of which two talukas purposively selected for the study. Four villages from each talukas selected randomly and fifteen farmers from each village selected on the lottery basis. Thus total sample size 120. Ex-post facto research design was adopted in this study. For the study the variables taken namely Education, Occupation, Annual income, Social participation, Mass media exposure, Scientific orientation, Economic motivation and Innovativeness showed positive significant relationship with information management behaviour of pomegranate growers with 0.01 per cent level of probability. The variables Land holding, Area under pomegranate, Farming experience and extension contact showed positive significant relationship with information management behaviour of pomegranate growers with 0.05 per cent level of probability While Variables namely Size of family and Source of irrigation showed non- significant relationship with information management behaviour of pomegranate growers.

\section{Introduction}

Agriculture is not merely a source of income rather it is a culture. Agricultural sector has been one of the most important components of Indian economy. The contribution of agriculture to the overall Gross Domestic Product (GDP) of the country which has about 30.00 per cent in 1990-91 has reduce to
15.00 per cent in 2011-2012 and about 16.00 per cent in the year 2018 (1-4).

Now a day, Information is a basic necessity of everyday life. For anything and everything information required. Information can be obtained or retrieved from a variety of sources. Farmers constitute a particular group of users whose information need is very 
specific (5-8). The present paper deals with the information needs of the farmers' community in rural areas. In agriculture environment, relevant and timely information help farmers' community to take right decision to sustain the growth of agriculture activity. Use of information in agriculture sector is enhancing farming productivity in a number of ways. Providing information on weather trends, best practice in farming, timely access to market information helps farmers make correct decisions about what crops to plants and where to sell their product and buy inputs (9-11). There is large gap between our farmers field and research. In order to meet this gap we need proper extension and dissemination of technologies to reach out to our poor farmers (12-15). While cultivating pomegranate farmers and village community facing various problems like insufficient and inadequate information about pomegranate cultivation practices hence it is necessary to formulate effective extension strategies and also essential to find out whether farmers are undergoing any change in their information management behaviour or not. To bridge the gap between the research and adoption, many questions may arise like what extend to the extension personal satisfy the information needs of our farmer? What are the various credible sources of our farmers for seeking information? What is the information management behaviour of our pomegranate growing farmers? What are the problems pomegranate growing farmers faces in information management of pomegranate cultivation.

The main objectives of this study include to study profile of the pomegranate growers.

\section{Materials and Methods}

There are eight districts in Marathwada region. From there Aurangabad district was purposively selected for the research study on the basis of maximum number of pomegranate growers and production. There are nine talukas in Aurangabad district out of which two taukas i.e. Aurangabad and Phulambari were selected purposively for the study. From each taluka four villages were selected randomly. From each village fifteen farmers were selected on the lottery basis. Thus total sample size 120. Ex-post facto research design was adopted in this study, Statistically analyzed by using statistical techniques like Mean, Frequency and Percentage, Standard Deviation, Pearson's correlation coefficient (r). The interview schedule based on the objectives of the study was prepared for collecting data from the respondents. The schedule was formulated in consultation with the experts in the field of extension education, by reviewing the relevant literature.

\section{Results and Discussion}

From the present study it was observed that $41.67 \%$ of the pomegranate growers were educated up to high school level and education had significant relationship with information management behaviour of pomegranate growers. $55.00 \%$ of the pomegranate growers belongs to small family size and it was non-significantly related with information management behaviour of pomegranate growers followed by $75.84 \%$ of the pomegranate growers had medium level of annual income and it was significantly related with the information management behaviour. $36.67 \%$ of the pomegranate growers had small land holding and it was significantly related with information management behaviour of pomegranate growers followed by $63.34 \%$ of the pomegranate growers had high area under pomegranate cultivation and it was significantly related with information management behaviour of pomegranate growers. From the given study another results 
observed that $56.67 \%$ of the pomegranate growers had medium level of farming experience and had significant relationship with information management behaviour of pomegranate growers. $67.50 \%$ of the pomegranate growers did only farming as a occupation and it was significantly related with information management behaviour of pomegranate growers. $96.67 \%$ of the pomegranate growers had only well as a source of irrigation and it was non-significant relationship with information management behaviour of pomegranate growers.83.34\% of the pomegranate growers had medium level of social participation and was significantly related with information management behaviour of pomegranate growers. Another result came from the given study that $81.67 \%$ of the pomegranate growers belongs to medium level of extension contact and had significant relationship with information management behaviour of pomegranate growers. 59,16 \% of the pomegranate growers had medium exposure towards mass media and it was significantly related with information management behaviour of pomegranate behaviour. $4250 \%$ of the pomegranate growers had high level of scientific orientation and had significant relationship with information management behaviour of pomegranate growers. $70.83 \%$ of the pomegranate growers belong to medium level of economic orientation and it was significantly related with information management behaviour of pomegranate growers. $6334 \%$ of the pomegranate growers were belongs to medium level of innovativeness and had significant relationship with information management behaviour of pomegranate growers (Table 1).

Table.1

\begin{tabular}{|c|c|c|c|c|}
\hline Sr. No. & Category/ Characteristics & \multicolumn{2}{|c|}{$\begin{array}{c}\text { Pomegranate Farmers } \\
(\mathbf{n = 1 2 0})\end{array}$} & r value \\
\hline $\mathbf{A}$ & Education & No. & $\%$ & \\
\hline $\mathbf{1}$ & Illiterate & 01 & 00.83 & \\
\hline $\mathbf{2}$ & Only read and write & 07 & 05.83 & \\
\hline $\mathbf{3}$ & Primary level & 14 & 11.67 & $\mathbf{0 . 8 2 1}^{* *}$ \\
\hline $\mathbf{4}$ & Middle school & 50 & 41.67 & \\
\hline $\mathbf{5}$ & College & 48 & 40.00 & \\
\hline $\mathbf{B}$ & Family size & & & \\
\hline $\mathbf{1}$ & Small (Up to 4 member) & 66 & 55.00 & \\
\hline $\mathbf{2}$ & Medium (5 to 7) & 48 & 40.00 & \multirow{2}{*}{$\mathbf{0 . 1 3 2}^{\text {Ns }}$} \\
\hline $\mathbf{3}$ & Large (>7) & 06 & 05.00 & \\
\hline $\mathbf{C}$ & Annual income & & & \\
\hline $\mathbf{1}$ & & & & \\
\hline $\mathbf{2}$ & Low & 06 & 05.00 & \multirow{2}{*}{ Medium } \\
\hline $\mathbf{3}$ & High & 23 & 19.16 & \\
\hline $\mathbf{D}$ & Land holding & & & \\
\hline & & & & \\
\hline
\end{tabular}




\begin{tabular}{|c|c|c|c|c|}
\hline 1 & Marginal (Up to $1.00 \mathrm{ha}$ ) & 24 & 20.00 & \\
\hline 2 & Small (1.01 to $2.00 \mathrm{ha})$ & 44 & 36.67 & \\
\hline 3 & Semi- medium (2.01 to $4.00 \mathrm{ha})$ & 31 & 25.83 & 0.274* \\
\hline 4 & Medium (4.01 to 10.00 ha) & 20 & 16.67 & \\
\hline 5 & Large (Above 10.01 ha ) & 01 & 00.83 & \\
\hline $\mathbf{E}$ & Area under pomegranate & & & \\
\hline 1 & Marginal (Up to $1.00 \mathrm{ha}$ ) & 02 & 01.66 & \\
\hline 2 & Small $(1.01$ to $2.00 \mathrm{ha})$ & 76 & 63.34 & \\
\hline 3 & Semi-medium (2.01 to $4.00 \mathrm{ha}$ ) & 39 & 32.50 & $0.212 *$ \\
\hline 4 & Medium (4.01 to 10.00 ha ) & 03 & 02.50 & \\
\hline 5 & Large ( Above $10.01 \mathrm{ha}$ ) & 00 & 00.00 & \\
\hline $\mathbf{F}$ & Farming experience & & & \\
\hline 1 & Low & 29 & 24.16 & \\
\hline 2 & Medium & 68 & 56.67 & $0.210 *$ \\
\hline 3 & High & 23 & 19.17 & \\
\hline $\mathbf{G}$ & Occupation & & & \\
\hline 1 & Farming & 81 & 67.50 & \\
\hline 2 & Farming + business & 34 & 28.34 & $0.369 * *$ \\
\hline 3 & Farming + labour & 00 & 00.00 & \\
\hline 4 & Farming + service & 05 & 04.16 & \\
\hline $\mathbf{H}$ & Source of irrigation & & & \\
\hline 1 & No source & 00 & 00.00 & \\
\hline 2 & River & 00 & 00.00 & $-0.125^{\mathrm{NS}}$ \\
\hline 3 & Well & 116 & 96.67 & \\
\hline 4 & Canal & 04 & 03.33 & \\
\hline $\mathbf{I}$ & Social participation & & & \\
\hline 1 & Low & 01 & 00.83 & \\
\hline 2 & Medium & 100 & 83.34 & $0.892 * *$ \\
\hline 3 & High & 19 & 15.83 & \\
\hline $\mathbf{J}$ & Extension contact & & & \\
\hline 1 & Low & 04 & 03.33 & \\
\hline 2 & Medium & 98 & 81.67 & $0.271 * *$ \\
\hline 3 & High & 18 & 15.00 & \\
\hline $\mathbf{K}$ & Mass media exposure & & & \\
\hline 1 & Low & 16 & 13.34 & \\
\hline 2 & Medium & 71 & 59.16 & $0.760 * *$ \\
\hline 3 & High & 33 & 27.50 & \\
\hline
\end{tabular}




\begin{tabular}{|c|c|c|c|c|}
\hline $\mathbf{L}$ & Scientific orientation & \multicolumn{2}{|l|}{} & \\
\hline $\mathbf{1}$ & Low & 26 & 21.66 & \\
\hline $\mathbf{2}$ & Medium & 43 & 35.84 & $\mathbf{0 . 9 5 2} * *$ \\
\hline $\mathbf{3}$ & High & 51 & 42.50 & \\
\hline $\mathbf{M}$ & Economic motivation & & & \\
\hline $\mathbf{1}$ & Low & 10 & 08.34 & \\
\hline $\mathbf{2}$ & Medium & 85 & 70.83 & $\mathbf{0 . 9 1 7} * *$ \\
\hline $\mathbf{3}$ & High & 25 & 20.83 & \\
\hline $\mathbf{N}$ & Innovativeness & & & \\
\hline $\mathbf{1}$ & & & & \\
\hline $\mathbf{2}$ & Low & 13 & 10.83 & \\
\hline $\mathbf{3}$ & Medium & 76 & 63.34 & $\mathbf{0 . 3 4 4} * *$ \\
\hline
\end{tabular}

\section{References}

1. Adebayo, S. A. and Oladele, O. I. (2013). Socio-economic status of organic vegetable farmers in south west Nigeria. Journal of Food, Agriculture and Environment. 11(2): 397-402.

2. Anitha B. A study on entrepreneurial behaviour and market participation of farm women in Bangalore rural district of Karnataka. M.Sc. (Agri.) Thesis, University of Agricultural Sciences, Bangalore, 2004.

3. Bhople, P.P., Shinde, P.S. and Bhople, S.R. (1995). Pattern of information management by orange growers. Maharashtra Journal of Extension Education., 17: 184-187.

4. Borole, P. Y. (2010). Attitude of demonstrated paddy growers towards SRI technique. Unpublished M.Sc. (Agri.) Thesis, AAU, Anand.

5. Chaudhary, Mohanlal (2010). A study on pesticide using behaviour of paddy growers in Khambhat taluka of Anand district (Unpublished) M.Sc. (Agri.), AAU, Anand.

6. Christian, B. M. (2001). A study on extent of adoption of IPM strategy by cotton growers of Vadodara district of Gujarat state. M.Sc. (Agri.) thesis, (Unpublished). GAU., S. K. Nagar.
7. Desale, M. M. (2009). Extent of adoption of hybrid castor production technology by the farmers in Kheda district of Gujarat state, (Unpublished) M.Sc. (Agri.) Thesis, AAU, Anand.

8. Manjunath, T. 2010. A study on knowledge and adoption of plant protection measures by paddy growers of Raichur district. M.Sc. (Ag.) Thesis. University of Agricultural Sciences, Dharwad.

9. Mate, P.S. (2005). A study of knowledge and adoption of improved potato cultivation practices by the farmers in Pune district, M.Sc. (Agri.) thesis, MPKV, Rahuri.

10. Nadre KR. A study on constraints in adoption of recommended practices of cotton in Aurangabad and Jalna districts. MANAGE Extension Research Review. 2000; 1 (2): 66-76.

11. Potsangbam R. (2017). Entrepreneurial behaviour of brinjal growers M.Sc. (Agri.) Unpublished Dr. PDKV Akola (MS).

12. Raghavendra, H. N. (1997. A study on knowledge and adoption behaviour of arecanut farmers of South Canara district, Karnataka State. MS.c. (Ag.) Thesis, University of Agricultural Sciences, Bangalore, Karnataka.

13. Ram D, Rangslang D, Prasad A, Pandey 
D.K, Upadhaya A.D. 2011. Communication behaviour of potato growers in Meghalaya. Journal of communication Studies 29: 39-46

14. Saha, B and Devi, R. 2014. Information management behaviour of traditional fish farmers in Assam. Indian Res. J. Ext. Edu.
14 (1): 10-14.

15. Sawant, P. A. (1999). An experimental study on the effectiveness of different modes of presentation of information on mushroom cultivation through television. Ph.D. Thesis, University of Agricultural Sciences, Dharwad, Karnataka.

\section{How to cite this article:}

Bhoyar, S. D., R. D. Ahire and Kapse, P. S. 2020. Study Profile of the Pomegranate Growers. Int.J.Curr.Microbiol.App.Sci. 9(12): 2006-2011. doi: https://doi.org/10.20546/ijcmas.2020.912.237 